\title{
EFFECT OF DIFFERENT COMBINATIONS OF PAPAIN-BASED GELS ON DISSOLVING PULP TISSUE
}

\author{
EFEITO DE DIFERENTES COMBINAÇÕES DE GÉIS À BASE DE PAPAÍNA NA \\ DISSOLUÇÃO DO TECIDO PULPAR
}

\section{Matheus Melo PITHON ${ }^{1}$; Rogério LACERDA-SANTOS ${ }^{2}$; Gabriel Couto de OLIVEIRA ${ }^{3}$; Caio Sousa FERRAZ ${ }^{3}$; Matheus Souza Campos COSTA ${ }^{4}$; Maíra Mercês BARRETO ${ }^{5}$; Daniel de Melo SILVA}

1. Professor, Department of Orthodontics, State University of Southwest Bahia, Jéquie, Bahia, Brazil. matheuspithon@gmail.com; 2. Professor, Department of Orthodontics, Federal University of Juiz de Fora, Governador Valadares, Minas Gerais, Brazil. lacerdaorto@gmail.com; 3. Graduated in Dentistry, Department of Orthodontics, State University of Southwest Bahia, Jéquie, Bahia, Brazil; 4. Student of Dentistry, Department of Orthodontics, State University of Southwest Bahia, Jéquie, Bahia, Brazil; 5. Professor, Department of Chemistry, State University of Southwest Bahia, Jéquie, Bahia, Brazil;

\begin{abstract}
The focus of this study was to evaluate the capacity to dissolve pulp tissue of various combinations of papain-based gels and other antimicrobial agents. 105 bovine pulps were used, of standardized sizes, fragmented into $15 \mathrm{~mm}$-sized portions and weighed on an analytical balance, divided into 7 groups $(\mathrm{n}=15): 1-0.9 \%$ Saline Solution (negative control); 2- 8\% Papain gel; 3- 8\% Papain gel $+0.5 \%$ Chloramine; $4-0.5 \%$ Chloramine gel; 5- 8\% Papain gel $+2 \%$ Chlorhexidine; 6- 2\% Chlorhexidine gel; and 7- 5.25\% Sodium Hypochlorite solution (positive control). After initial weighing, the pulp fragments were inserted in test tubes for dissolution for time intervals of 30, 60, 90 and 120 minutes, and then weighed again. The data were analyzed using the Kruskal-Wallis and Mann-Whitney tests $(\mathrm{p}<0.05)$. In the time interval of 120 minutes the $0.5 \%$ chloramine gel demonstrated $64.9 \%$ ability to pulp dissolve, followed by $8 \%$ papain gel with $61.3 \%$; papain associated with $0.5 \%$ chloramine, $58 \%$; and papain associated with $2 \%$ chlorhexidine, 55.4\%; which showed statistically significant difference with 5.25\% Sodium Hypochlorite $(\mathrm{p}<0.05)$. All the gels that contained papain and the $0.5 \%$ chloramine gel promoted pulp tissue dissolution, however on a significantly lower scale than $5.25 \%$ sodium hypochlorite. The $2 \%$ chlorhexidine demonstrated no capacity to dissolve pulp, as did the control.
\end{abstract}

KEY WORDS: Papain. Dental pulp. Chlorhexidine. Dissolution.

\section{INTRODUCTION}

The success of endodontic treatment is mainly related to microbial control (KAKEHASHI et al., 1965), by the use of chemical substances with antimicrobial activity and the capacity to dissolve organic matter (HEGDE et al., 2016), in addition to have lubricating properties and low cytotoxicity (SAFAVI et al., 1990).

Sodium hypochlorite $(\mathrm{NaOCl})$ is the most used endodontic irrigant at present, although there are researchers (MORRIS et al., 2001; DAMETTO et al., 2005; MOREIRA et al., 2009; BEHRENTS et al., 2012; KERBL et al., 2012; PASCHOALINO et al., 2012; GUNESER et al., 2015) proposing other alternatives such as chloramine, chlorhexidine, papain gel (DUARTE et al., 2001) and Octenidine and QMix 2in1 (ARSLAN et al., 2015). $\mathrm{NaOCl}$ is highly cytotoxic, has allergenic potential and harms the bond of resin cements because it causes changes in the collagen fibers of root dentin (MORRIS et al., 2001; MOREIRA et al., 2009), and it is capable of changing the integrity of spongy bone if it passes through the apical foramen (BEHRENTS et al.,
2012; KERBL et al., 2012; PASCHOALINO et al., 2012).

Thus, the use of other irrigant solutions, such as chlorhexidine gluconate has been justified (OKINO et al., 2004; FERRAZ et al., 2007; AKGUN et al., 2013; BOLLA et al., 2013), due to its antimicrobial action, substantivity, less odor and cytotoxicity than $\mathrm{NaOCl}$ (DAMETTO et al., 2005). However, chlorhexidine in gel and also in an aqueous solution show no potential to dissolve organic matter (OKINO et al., 2004). Another irrigant that has been suggested is papain gel, because it is a proteolytic enzyme, has the capacity to dissolve pulp tissue, in addition it has bactericidal action, as the chloramines (DUARTE et al., 2001).

Considering that the presence of infected pulp remainders, particularly in the regions where mechanical instrumentation is not effective, it is a factor responsible for endodontic treatment failure, the aim of this study was to evaluate the capacity to dissolve pulp tissue of various combinations of papain-based gels and other antimicrobial agents such as chlorhexidine and chloramine. 


\section{MATERIAL AND METHODS}

A random selection was made of 105 incisors extracted from bovine mandibles, which were immediately stored in physiological solution. The dental pulps were removed on the same day as the teeth were extracted, by fracturing the incisors in the cervical region, separating the crown from the root in the buco-lingual direction with the help of a stabilizer of the lathe type on the tooth root, followed by fracturing the crown with a metal device of $4.90 \mathrm{~N}$, under manual pressure, performed in the pathology laboratory of the State University of Southwest Bahia.

The pulp was completely removed from the root by traction with hemostatic forceps, with the help of a caliper and a scalpel. The pulp was measured and cut, into standardized $15 \mathrm{~mm}$ portions from the middle thirds, size corresponding to approximately $60 \%$ of the total surface area of the content of the pulp sample, discarding the cervical and apical portions. The fragments were washed for 30 seconds with saline solution and enveloped in transparent plastic PVC film (Royal Pack, Paulista, Brazil), and stored at a temperature of $-20^{\circ} \mathrm{C}$ until they were used. This study was approved by the ethics committee in animal research, CEP:468/2015.

The formulations of the papain-based, chlorhexidine and chloramine gels, used to evaluate the capacity to dissolve pulp tissue, were prepared from the solution of these substances in the general Chemistry Laboratory of the State University of Southeast Bahia. Sodium hypochlorite was formulated in a concentration of $5.25 \%$ and adjusted to $\mathrm{pH} 9.0$ with the addition of boric acid. All substances, except sodium hypochlorite, were produced in Aristoflex ${ }^{\circledR}$ gel base - Ammonium Acryloyldimethyltaurate / VP Copolymer (Clariant International Ltd., Muttenz, Switzerland), and remained stored under refrigeration until they were used.

Seven experimental groups $(n=15)$ were established, as follows: Group 1 (Saline solution $0.9 \% \mathrm{NaCl}$, Negative Control), Group 2 (8\% Papain gel), Group 3 (8\% Papain gel $+0.5 \%$ chloramine gel), Group 4 ( $0.5 \%$ chloramine gel), Group 5 (8\% Papain gel $+2 \%$ chlorhexidine gel), Group $6(2 \%$ chlorhexidine gel) and Group 7 (5.25\% Sodium Hypochlorite solution - NaOCl, Positive Control).

To perform the dissolution process, the pulp fragments were removed from the freezer at $-20^{\circ} \mathrm{C}$ and allowed to return to ambient temperature. After this, they were washed for 30 seconds with the saline solution, lightly dried on filter paper for the same period of time and weighed on a precision analytical balance (Shimadzu AW-220, Tokyo, Japan). After weighing the fragments, they were placed in test tubes with $5 \mathrm{~mL}$ of the substance to be analyzed. At the end of each time interval of 30, 60, 90 and 120 minutes, the test substances were changed and the pulp fragments were washed again, dried and weighed according to the pre-established criteria.

\section{Statistical procedure}

Statistical analyses were performed with the program SPSS 15.0 (SPSS Inc., Chicago, Illinois, USA). Descriptive statistical analysis including mean and standard deviation were calculated for the groups evaluated. The statistical method was chosen based on the model of distribution and variance of data evaluated by the Kolmogorov-Smirnov and Levene tests, respectively. The mean pulp dissolution values were statistically analyzed using the non-parametric Kruskal-Wallis and MannWhitney tests $(\mathrm{p}<0.05)$.

\section{RESULTS}

The sodium hypochlorite almost completely degraded the pulp fragments $(95.7 \%)$ at 30 minutes $(p<0.05)$, followed by the agents with lower capacity to dissolve: $8 \%$ Papain associated with $2 \%$ chlorhexidine (37.6\%); 8\% Papain associated with $0.5 \%$ Chloramine (29\%); 8\% Papain (27.7\%) and $0.5 \%$ Chloramine (19.5\%) (Figure 1) without statistical significant difference among them $(p>0.05)$ (Table 1).

Over the immersion times of 60,90 and 120 minutes the pulp dissolution gradually increased. At 60 minutes $5.25 \%$ Sodium Hypochlorite demonstrated its greatest potential ability to dissolve $100 \%$ of the pulp samples $(p<0.05)$.

At 120 minutes $0.5 \%$ chloramine demonstrated $64.9 \%$ dissolution ability, and $8 \%$ papain in gel dissolved $61.3 \%$; papain with $0.5 \%$ chloramine dissolved 58\%; papain with $2 \%$ chlorhexidine dissolved $55.4 \%$. There was statistically significant difference of these groups with $5.25 \%$ Sodium Hypochlorite $(\mathrm{p}<0.05)$.

The $2 \%$ chlorhexidine and the negative control groups demonstrated no capacity to dissolve pulp $(p>0.05)$ throughout the experiment (Table 1).

The groups of $8 \%$ Papain, 8\% Papain + $0.5 \%$ Chloramine, $0.5 \%$ Chloramine, $8 \%$ Papain + $2 \%$ Chlorhexidine, 2\% Chlorhexidine and 5.25\% $\mathrm{NaOCl}$ demonstrated statistically significant difference between the initial period with the periods of 60 minutes, 90 minutes and 120 minutes $(\mathrm{p}>0.05)$. 
Percentage of dissolution

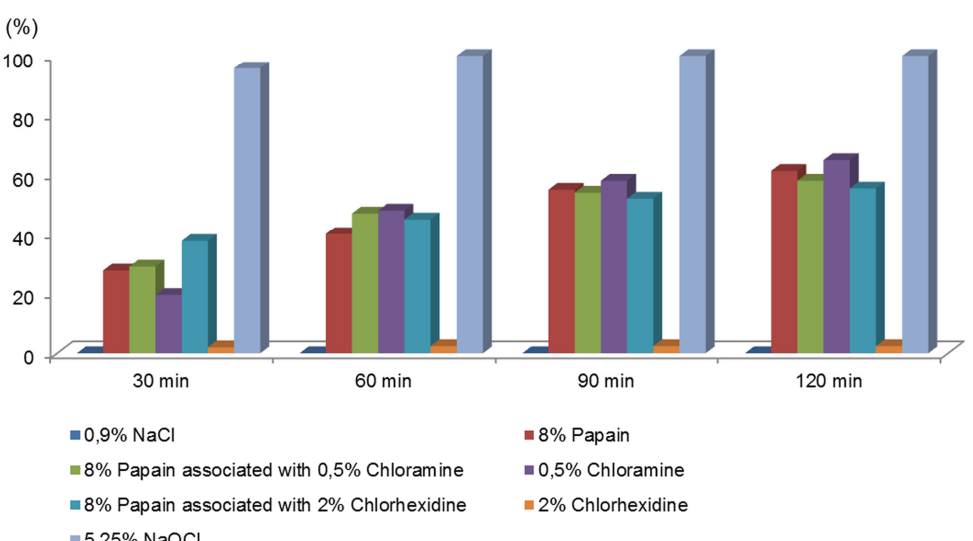

Figure 1: Percentage of the dissolving of pulp tissue at different times

Table 1: Mean weight in grams of the pulp fragments initially and after times of immersion in the test solutions.

\begin{tabular}{|c|c|c|c|c|c|c|c|c|c|c|c|}
\hline \multirow{3}{*}{\multicolumn{2}{|c|}{ Groups }} & \multicolumn{10}{|c|}{ Times of immersion } \\
\hline & & \multicolumn{2}{|l|}{ Initial } & \multicolumn{2}{|l|}{$30 \mathrm{~min}$} & \multicolumn{2}{|l|}{$60 \mathrm{~min}$} & \multicolumn{2}{|l|}{$90 \mathrm{~min}$} & \multicolumn{2}{|l|}{$120 \mathrm{~min}$} \\
\hline & & Mean (SD) & $\mathbf{S t}^{*}$ & Mean (SD) & $\mathbf{S t}^{*}$ & Mean (SD) & $\mathbf{S t}^{*}$ & Mean (SD) & $\mathbf{S t}^{*}$ & Mean (SD) & $\mathbf{S t}^{*}$ \\
\hline 1 & $0.9 \% \mathrm{NaCl}^{\dagger}$ & $0.0103(0.0003)$ & $\mathrm{Aa}$ & $0.0104(0.0003)$ & $\mathrm{Ab}$ & $0.0103(0.0002)$ & $\mathrm{Aa}$ & $0.0103(0.0005)$ & $\mathrm{Aa}$ & $0.0103(0.0003)$ & $\mathrm{Aa}$ \\
\hline 2 & 8\% Papain & $0.0101(0.0004)$ & $\mathrm{Aa}$ & $0.0073(0.0004)$ & $\mathrm{Bab}$ & $0.0061(0.0003)$ & $\mathrm{Bbc}$ & $0.0044(0.0003)$ & Bcd & $0.0039(0.0002)$ & $\mathrm{Bd}$ \\
\hline 3 & $\begin{array}{l}8 \% \text { Papain }+0.5 \% \\
\text { Chloramine }\end{array}$ & $0.0100(0.0004)$ & $\mathrm{Aa}$ & $0.0071(0.0003)$ & $\mathrm{Bab}$ & $0.0053(0.0005)$ & $\mathrm{Bbc}$ & $0.0046(0.0004)$ & Bcd & $0.0042(0.0003)$ & $\mathrm{Bd}$ \\
\hline 4 & 0.5\% Chloramine & $0.0097(0.0005)$ & $\mathrm{Aa}$ & $0.0078(0.0002)$ & $\mathrm{Bab}$ & $0.0051(0.0002)$ & $\mathrm{Bbc}$ & $0.0040(0.0004)$ & Bcd & $0.0034(0.0004)$ & $\mathrm{Bd}$ \\
\hline 5 & $\begin{array}{l}8 \% \text { Papain }+2 \% \\
\text { Chlorhexidine }\end{array}$ & $0.0101(0.0003)$ & $\mathrm{Aa}$ & $0.0063(0.0005)$ & $\mathrm{Bab}$ & $0.0055(0.0003)$ & $\mathrm{Cbc}$ & $0.0047(0.0005)$ & Ccd & $0.0045(0.0003)$ & $\mathrm{Cd}$ \\
\hline 6 & 2\% Chlorhexidine & $0.0103(0.0003)$ & $\mathrm{Aa}$ & $0.0101(0.0004)$ & $\mathrm{Aa}$ & $0.0100(0.0004)$ & $\mathrm{Ab}$ & $0.0100(0.0002)$ & $\mathrm{Ab}$ & $0.0100(0.0003)$ & $\mathrm{Ab}$ \\
\hline 7 & $5.25 \% \mathrm{NaOCl}^{\#}$ & $0.0094(0.0007)$ & $\mathrm{Aa}$ & $0.0004(0.0000)$ & $\mathrm{Ba}$ & $0.0000(0.0000)$ & $\mathrm{Cb}$ & $0.0000(0.0000)$ & $\mathrm{Cb}$ & $0.0000(0.0000)$ & $\mathrm{Cb}$ \\
\hline
\end{tabular}

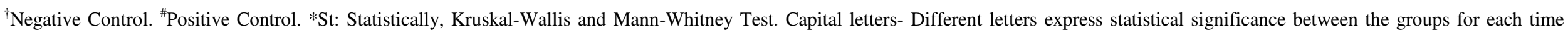
$(\mathrm{p}<0.05)$. Lowercase Letters - Different letters express statistical significance between the times for each group ( $<<0.05)$. SD: Standard Deviation. 


\section{DISCUSSION}

In medicine, papain is widely used and demonstrated no significant allergenic properties in humans (DA SILVA et al., 2010). In dentistry, papain gel associated with $0.5 \%$ chloramine is used in the chemical-mechanical removal of carious dental tissues (CARRILLO et al., 2008; GIANINI et al., 2010; AMARAL et al., 2011), and it has been indicated as an irrigant solution for teeth requiring endodontic treatment (DUARTE et al., 2001). According to MIYAGI et al. (2006) papain up to the concentration of $8 \%$ associated with $0.5 \%$ chloramine has shown no cytotoxicity, and no mutagenic potential (LOPES et al., 2008; DA SILVA et al., 2010).

In this study, the test tubes were static because substances with different viscosities were being compared (liquid and gel). Agitation could influence of the potential to dissolve pulp tissue (NIEWIEROWSKI et al., 2015), because of variation in the amount of solution that would contact with the fragments and the mechanical action performed by movement of the fluids.

It was noted that $\mathrm{NaOCl} 5.25 \%$ solution showed the greatest potential to dissolve pulp tissue. After 30 minutes the $\mathrm{NaOCl}$ had degraded almost the entire fragment, (95.7\%), with great effectiveness in the dissolution of organic matter, which corroborates with the findings of other studies (IRALA et al., 2010; STOJICIC et al., 2010; GUNESER et al., 2015; HEGDE et al., 2016). Over the same period, it has shown that $8 \%$ papain associated with $2 \%$ chlorhexidine, promoted a faster dissolution compared with pure $8 \%$ papain, and papain with $0.5 \%$ chloramine. Suggests that, the ionic combination between free radicals present in chlorhexidine/papain increase the papain proteolytic capacity on the organic matter, in the initial period of 30 minutes. Whereas in the time intervals of 60 and 90 minutes these rates were more even, with a slight predominance for chloramine, but without statistical difference.

The groups of gels that contained papain in the formulation and the $0.5 \%$ chloramine group achieved pulp dissolution of $55.4 \%$ to $64.9 \%$ at the end of 120 minutes, which was statistically significant in comparison with $0.9 \% \mathrm{NaCl}$ (negative control) and 2\% chlorhexidine gel. Thus a gradual degradation of the fragments was observed, however, at a much slower speed compared with $\mathrm{NaOCl}$.

The $2 \%$ chlorhexidine group underwent a small loss of weight during the process, however it was not statistically significant compared to the control group, which is in agreement with other studies (MARLEY et al., 2001; OKINO et al., 2004), and demonstrated its inability to dissolve organic materials (MARLEY et al., 2001).

Among the morphological changes observed, $5.25 \% \mathrm{NaOCl}$ promoted rapid dissolution with characteristics of tissue dehydration. This was also observed with $0.5 \%$ chloramine, however, with slower dissolution. When exposed to $2 \%$ chlorhexidine dehydration followed by tissue hardening was observed, but without dissolution. The papain-containing gels demonstrated that the pulps underwent a slow dissolution, without the characteristic of dehydration, and remained softened. In saline solution, the pulp fragments maintained the same characteristics of initial tissue.

In the comparison between pulp degradation times for each gel, 8\% Papain, 8\% Papain $+0.5 \%$ Chloramine, $0.5 \%$ Chloramine, $8 \%$ Papain $+2 \%$ Chlorhexidine, $2 \%$ Chlorhexidine and $5.25 \%$ $\mathrm{NaOCl}$ did not show statistically significant difference between the initial period and 30 minutes, although after 30 minutes the $5.25 \% \mathrm{NaOCl}$ has demonstrated great pulp dissolution capacity. Considering that the $\mathrm{NaOCl}$ solution has some undesirable properties, such as tissue irritation and allergenic potential (CALISKAN et al., 1994; DUARTE et al. 2001; GUNESER et al., 2015), it encourages the search for new substances with better characteristics. In this context, 2\% chlorhexidine appears to be a promising material, nevertheless, studies (TULUNOGLU et al. 1998; WACHLAROWICZ et al., 2007; MOREIRA et al., 2009) have shown evidence that it may affect the bond between certain adhesive systems and dentin when used as an intracanal irrigant (SIMSEK et al. 2013).

The results obtained in this study for $8 \%$ papain and its associations and/or $0.5 \%$ chloramine, demonstrated promising results as an alternative material for use in clinical practice. However, further studies are necessary to evaluate whether if $8 \%$ papain and/or $0.5 \%$ chloramine are capable of affecting the bond between adhesive systems and dentin, after being used as an intracanal irrigant.

\section{CONCLUSIONS}

All the gels that contained papain, and the $0.5 \%$ chloramine gel promoted pulp tissue dissolution, however on a significantly lower scale than $5.25 \%$ sodium hypochlorite.

The $2 \%$ chlorhexidine demonstrated no capacity to dissolve pulp, as did the control. 
RESUMO: O foco deste estudo foi avaliar a capacidade de dissolução do tecido pulpar de várias combinações de géis à base de papaína e outros agentes antimicrobianos. Foram utilizadas 105 polpas bovinas, de tamanhos padronizados, fragmentadas em porções de $15 \mathrm{~mm}$ e pesadas em balança analítica, divididas em 7 grupos $(\mathrm{n}=15): 1-0,9 \%$ de Solução Salina (controle negativo); 2- 8\% de gel de papaína; 3- 8\% de gel de papaína + 0,5\% de cloramina; 4- 0,5\% de gel de cloramina; 5 - $8 \%$ de gel de papaína $+2 \%$ de clorhexidina; 6 - $2 \%$ de gel de clorexidina e 7- 5,25\% de solução de hipoclorito de sódio (controlo positivo). Após pesagem inicial, os fragmentos de polpa foram inseridos em tubos de ensaio para dissolução durante intervalos de tempo de 30, 60, 90 e 120 minutos e depois pesados novamente. Os dados foram analisados pelos testes de Kruskal-Wallis e Mann-Whitney ( $\mathrm{p}<0,05)$. No intervalo de tempo de 120 minutos o gel de cloramina a $0,5 \%$ demonstrou $64,9 \%$ de capacidade de dissolver polpa, seguido pelo gel de papaína a $8 \%$ com $61,3 \%$; papaína associada a $0,5 \%$ de cloramina, 58\%; e papaína associada a clorexidina a 2\%, 55,4\%; que apresentaram diferença estatisticamente significativa com hipoclorito de sódio a 5,25\% ( $\mathrm{p}<0,05)$. Todos os géis que continham papaína e o gel de cloramina a $0,5 \%$ promoveram a dissolução do tecido de polpa, contudo em uma escala significativamente inferior a $5,25 \%$ de hipoclorito de sódio. A clorexidina a $2 \%$ não demonstrou capacidade para dissolver a polpa, assim como o controle.

PALAVRAS-CHAVE: Papaína. Polpa dentária. Clorexidina. Dissolução.

\section{REFERENCES}

AKGUN, O. M.; POLAT, G. G.; AKYOL, M.; ALTUN, C.; BASAK, F. The effect of irrigation solutions with or without sodium ascorbate on the microleakage of class II composite restorations. J. Ped. Dent. Mumbai, v. 1, n. 1, p. 1-7, Jan-Apr. 2013. https://doi.org/10.4103/2321-6646.113849

AMARAL, F. L. B.; FLORIO, F. M.; AMBROSANO, G. M. B.; BASTING, R. T. Morphology and microtensile bond strength of adhesive systems to in situ-formed caries-affected dentin after the use of a papain-based chemomechanical gel method. Am. J. Dent. San Antonio, v. 24, n. 1, p. 13-9, Feb. 2011.

ARSLAN, D.; GUNESER, M. B.; KUSTARCI, A.; ER, K.; SISO, S. H. Pulp tissue dissolution capacity of QMix 2in1 irrigation solution. Eur. J. Dent. Ankara, v. 9, n. 3, p. 423-7, Jul-Sep. 2015.

BEHRENTS, K. T.; SPEER, M. L.; NOUJEIM, M. Sodium hypochlorite accident with evaluation by cone beam computed tomography. Int. Endod. J. Oxford, v. 45, n. 5, p. 492-8, May. 2012.

BOLLA, N.; NALLI, S. M. S.; KUMAR, K. K. R.; RAJ, S. Cytotoxic evaluation of two chlorine-releasing rrigating solutions on cultured human periodontal ligament fibroblasts. J. Dr. NTR. Univ. Health Sc. Mumbai, v .2, n. 1, p. 42-6, Mar. 2013. https://doi.org/10.4103/2277-8632.108512

CALISKAN, M. K.; TURKUN, M.; ALPER, S. Allergy to sodium hypochlorite during root canal therapy: a case report. Int. Endod. J. Oxford, v. 27, n. 3, p. 163-7, May. 1994.

CARRILLO, C. M.; TANAKA, M. H.; CESAR, M. F.; CAMARGO, M. A.; JULIANO, Y.; NOVO, N. F. Use of papain gel in disabled patients. J. Dent. Child. Chicago, v. 75, n. 3, p. 222-8. Sep-Dec. 2008.

DA SILVA, C. R.; OLIVEIRA, M. B.; MOTTA, E. S.; DE ALMEIDA, G. S.; VARANDA, L. L.; DE PADULA, M.; LEITÃO, A. C.; ARAÚJO, A. C. Genotoxic and Cytotoxic Safety Evaluation of Papain (Carica papaya L.) Using In Vitro Assays. J. Biomed. Biotechnol. Akron, v. 19, n. 3, p. 87-98, May. 2010.

DAMETTO, F. R.; FERRAZ, C. C.; GOMES, B. P.; ZAIA, A. A.; TEIXEIRA, F. B.; DE SOUZA-FILHO, F. $\mathrm{J}$. In vitro assessment of the immediate and prolonged antimicrobial action of chlorhexidine gel as an endodontic irrigant against Enterococcus faecalis. Oral Surg. Oral Med. Oral Pathol. Oral Radiol. Endod. St. Louis, v. 99, n. 6, p. 768-72, Jun. 2005. https://doi.org/10.1016/j.tripleo.2004.08.026

DUARTE, M. A. H.; YAMASHITA, J. C.; LANZA, P.; FRAGA, S. C.; KUGA, M. C. Influence of endodontic irrigation with papain gel on apical sealing. Salusvita. Bauru, v. 20, n. 2, p. 27-33, Mar. 2001. 
FERRAZ, C. C.; GOMES, B. P.; ZAIA, A. A.; TEIXEIRA, F. B.; SOUZA-FILHO, F. J. Comparative study of the antimicrobial efficacy of chlorhexidine gel, chlorhexidine solution and sodium hypochlorite as endodontic irrigants. Braz. Dent. J. Ribeirão Preto, v. 18, n. 4, p. 294-8, Mar. 2007.

GIANINI, R. J.; DO AMARAL, F. L.; FLORIO, F. M.; BASTING, R. T. Microtensile bond strength of etchand-rinse and self-etch adhesive systems to demineralized dentin after the use of a papain-based chemomechanical method. Am. J. Dent. San Antonio, v. 23, n. 1, p. 23-8, Feb. 2010.

GUNESER, M. B.; ARSLAN, D.; USUMEZ, A. Tissue dissolution ability of sodium hypochlorite activated by photon-initiated photoacoustic streaming technique. J. Endod. Chicago, v. 41, n. 5, p. 29-32, May. 2015.

HEGDE, R. J.; BAPNA, K. Comparison of removal of endodontic smear layer using ethylene glycol bis (betaamino ethyl ether)-N, N, N', N'-tetraacetic acid and citric acid in primary teeth: A scanning electron microscopic study. Contemp. Clin. Dent. Mumbai, v. 7, n. 2, p. 216-20, Apr-Jun. 2016.

IRALA, L. E.; GRAZZIOTIN-SOARES, R.; SALLES, A. A.; MUNARI, A. Z.; PEREIRA, J. S. Dissolution of bovine pulp tissue in solutions consisting of varying $\mathrm{NaOCl}$ concentrations and combined with EDTA. Braz. Oral Res. São Paulo, v. 24, n. 3, p. 271-6, Jul-Sep. 2010.

KAKEHASHI, S.; STANLEY, H. R.; FITZGERALD, R. J. The Effects of Surgical Exposures of Dental Pulps in Germ-Free and Conventional Laboratory Rats. Oral Surg. Oral Med. Oral Pathol. St. Louis, v. 20, n. 1, p. 340-9, Sep. 1965. https://doi.org/10.1016/0030-4220(65)90166-0

KERBL, F. M.; DEVILLIERS, P.; LITAKER, M.; ELEAZER, P. D. Physical effects of sodium hypochlorite on bone: an ex vivo study. J. Endod. Chicago, v. 38, n. 3, p. 357-9, Mar. 2012.

https://doi.org/10.1016/j.joen.2011.12.031

LOPES, P. S.; RUAS, G. W.; BABY, A. R.; PINTO, C. A. S. O.; WATANABE, I.; VALESCO, M. V. R. E. A. In vitro safety assessment of papain on human skin: A qualitative Light and Transmission Electron Microscopy (TEM) study. Braz. J. Pharm. Sc. São Paulo, v. 44, n. 1, p. 151-156, Jan-Mar. 2008.

MARLEY, J. T.; FERGUSON, D. B.; HARTWELL, G. R. Effects of chlorhexidine gluconate as an endodontic irrigant on the apical seal: short-term results. J. Endod. Chicago, v. 27, n. 12, p. 775-778, Dec. 2001. https://doi.org/10.1097/00004770-200112000-00016

MIYAGI, S. P. H.; MELLO, I.; BUSSADORI, S. K.; MARQUES, M. M. Response of human pulp fibroblasts in culture to Papacárie gel. J. Dent. Univ. São Paulo. São Paulo, v. 18, n. 3, p. 245-249, Sep-Dec. 2006.

MOREIRA, D. M.; ALMEIDA, J. F.; FERRAZ, C. C.; GOMES, B. P.; LINE, S. R.; ZAIA, A. A. Structural analysis of bovine root dentin after use of different endodontics auxiliary chemical substances. J. Endod. Chicago, v. 35, n. 7, p. 1023-7, Jul. 2009. https://doi.org/10.1016/j.joen.2009.04.002

MORRIS, M. D.; LEE, K. W.; AGEE, K. A.; BOUILLAGUET, S.; PASHLEY, D. H. Effects of sodium hypochlorite and RC-prep on bond strengths of resin cement to endodontic surfaces. J. Endod. Chicago, v. 27 , n. 12, p. 753-7, Dec. 2001. https://doi.org/10.1097/00004770-200112000-00010

NIEWIEROWSKI, R. S.; SCALZILLI, L. R.; MORGENTAL, R. D.; FIGUEIREDO, J. A.; VIER-PELISSER, F. V.; BORBA, M. G.; GHISI, A. C. Bovine pulp tissue dissolution ability of irrigants associated or not to ultrasonic agitation. Braz. Dent. J. Ribeirão Preto, v. 26, n. 5, p. 537-40, Oct. 2015.

OKINO, L. A.; SIQUEIRA, E. L.; SANTOS, M.; BOMBANA, A. C.; FIGUEIREDO, J. A. Dissolution of pulp tissue by aqueous solution of chlorhexidine digluconate and chlorhexidine digluconate gel. Int. Endod. J.

Oxford, v. 37, n. 1, p. 38-41, Jan. 2004. https://doi.org/10.1111/j.1365-2591.2004.00749.x 
PASCHOALINO, M. D. E. A.; HANAN, A. A.; MARQUES, A. A.; GARCIA, L. D. A. F.; GARRIDO, A. B.; SPONCHIADO, E. C. J. R. Injection of sodium hypochlorite beyond the apical foramen--a case report. Gen. Dent. Chicago, v. 60, n. 1, p. 16-9, Jan-Feb. 2012.

SAFAVI, K. E.; SPANGBERG, L. S.; LANGELAND, K. Root canal dentinal tubule disinfection. J. Endod. Chicago, v. 16, n. 5, p. 207-10, May. 1990.

SIMSEK, N.; AKPINAR, K. E.; SUMER, Z. Evaluation of bacterial microleakage of root canals irrigated with different irrigation solutions and KTP laser system. Photomed. Laser Surg. Larchmont, v. 31, n. 1, p. 3-9, Jan. 2013. https://doi.org/10.1089/pho.2012.3308

STOJICIC, S.; ZIVKOVIC, S.; QIAN, W.; ZHANG, H.; HAAPASALO, M. Tissue dissolution by sodium hypochlorite: effect of concentration, temperature, agitation, and surfactant. J. Endod. Chicago, v. 36, n. 9, p. 1558-62, Sep. 2010. https://doi.org/10.1016/j.joen.2010.06.021

TULUNOGLU, O.; AYHAN, H.; OLMEZ, A.; BODUR, H. The effect of cavity disinfectants on microleakage in dentin bonding systems. J. Clin. Pediatr. Dent. Birmingham, v. 22, n. 4, p. 299-305, Summer. 1998.

WACHLAROWICZ, A. J.; JOYCE, A. P.; ROBERTS, S.; PASHLEY, D. H. Effect of endodontic irrigants on the shear bond strength of epiphany sealer to dentin. J. Endod. Chicago, v. 33, n. 2, p. 152-155, Feb. 2007. https://doi.org/10.1016/j.joen.2006.09.011 